Anna Shevyakova,

PhD, Research Associate of the Department of Marketing, South Ural State University (Chelyabinsk, Russia);

Berik Sharip,

DBA, Research Associate,

Almaty Management University (Almaty, Kazakhstan)

\title{
ASSESSMENT OF INNOVATIVE ACTIVITY OF KAZAKHSTAN HEALTHCARE ORGANIZATIONS
}

The article considers main tendencies of development of health of the Republic, the analysis of innovative activity of Kazakhstan medicine. The article reveals the essence and necessity of introduction of innovative technologies, which in modern conditions is one of the priority factors of organizational culture change. The everchanging conditions in the world lead to the emergence of new health professions and, according, is not only innovative approaches to education and competencies of professionals, but also to diversify the existing medical staff, who will be able to solve the burning problems faced by medical institutions.

Keywords: innovation, medicine, healthcare, medical technology, innovative activity.

DOI: 10.21272/mmi.2017.2-27

Introduction. Healthcare is an essential element of each social-economic system. It is responsible for the quality of life and productivity of the population. Its value in the future will increase the life expectancy and economic activity. New challenges of ensuring personal economic and human longevity require new organizational and technical solutions. The researchers focuse on the medical and social effect creating an innovative product or service.

Innovation in medicine is the outcome of the innovative activities implemented in the health organizations and bringing positive effects (medical, social, or economic). Innovation in medicine usually refers to the original technology of production and application of medicine or diagnostic drug, device or method with a high level of competitiveness in relation to those that already exist. Due to innovations in medicine, healthcare moved to the higher level, increasing duration and quality of human life, resulted in growing dynamic of high-tech medical aid not only abroad, but also in Kazakhstan. The experience of leading countries shows that the effective development of innovations in the state and private sectors of the national economy is impossible without integration of all elements of the national innovative system, at both the regional and state levels [5]

The object of study in this article. The main focus of this paper is the health of the Republic of Kazakhstan, the subject of the research - innovative activity of healthcare organizations of Kazakhstan. There are a lot of works devoted to the various aspects of innovations [1-4; 6-14, 16-17; 19-27, 29-34, 36-40].

The authors also used the theoretical and methodological development of international organizations (IMD, WEF, OECD, UN, IMF, WB, etc.), reports of national statistical services, as well as periodicals.

Analysis of the research literature. The healthcare system in Kazakhstan is a set of state bodies and subjects of health aimed at ensuring the rights of citizens to health protection and medical care. According to a number of authors, modernization and increasing the effectiveness of health care, and, first of all, the market of medical services is needed. This need stems from the fact that to date development of medical services market in Kazakhstan has not acquired the character of dependence to the needs of citizens as consumers of medical care. According to the report of the Global Competitiveness Index (hereinafter GCl) for 2014-2015, according to the "Health and primary education" 
indicator Kazakhstan ranked 96th out of 144 countries. According to the Human Development Index, Kazakhstan joined the group of countries with high development level, finishing in 70th place out of 187 countries [15; 18].

Being originated as order of patient to doctor, medical aid over time has gained the legal status of services. Medical services are considered as activities of healthcare subjects, with preventive, diagnostic, therapeutic or rehabilitative orientation towards a specific person.

The market of medical services as a developed system of relations of commodity and noncommodity exchange is the part of healthcare market, which directly affects the nation's health and quality of life of the population and requires state regulation of the market processes.

Development of healthcare and medical services market related to targeted improvement in quality, comprehensiveness, availability of services and introduction of innovative medical technology.

The main types of innovation in health are the following:

- pharmaceutical innovation is the development of new drugs;

- technological innovation associated with the emergence of new methods of prevention and treatment of diseases on the basis of existing drugs or new combinations of their application;

- organizational innovations involve improving the organization of labor and efficiency management;

- economic innovation is the introduction of new methods of planning and financing of medical institutions activities;

- information-technological innovations aimed at automation of information flows in the industry.

Analyzing innovative activities in healthcare, all innovations in this industry can be divided into the following four groups (Figure 1):

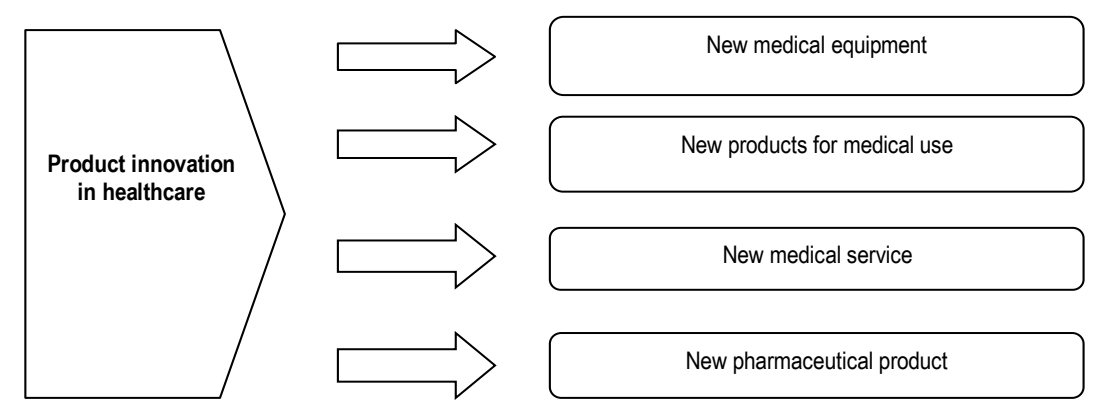

Figure 1 - Types of innovations in healthcare (compiled by the authors)

In full innovation in healthcare includes all types of research (fundamental, search, applied), development of innovations and introduction of a medical organization, i.e. the implementation of innovations.

Thanks to innovations in medicine, healthcare has reached a higher level, the duration and quality of human life is increasing, the dynamics of rendering high-tech medical care not only abroad, but also in the CIS countries, including in Kazakhstan, is growing.

Kazakhstan has accumulated a wealth of experience in reforming the economy: many difficulties had to be overcome, mistakes were corrected, shortcomings were eliminated, and some initial guidelines were revised. Some positive results of economic reforms have also been obtained: high rates of production growth were been achieved, and the living standard of the population has risen. Along with this, the influence of braking factors remains: the sectoral structure of the economy needs improvement, and the level of economic efficiency of production can not be considered satisfactory. 
Leading role in the reform belongs to institutional reforms, including the real maintenance of property rights, effective antitrust legislation and control over its implementation, strict banking supervision, insurance of bank deposits, etc. In their absence, a "system vacuum" arises, directly leading to the criminalization of economic life, the growth of the clan and shadow economy, the growth of non-payments.

Steady high dynamics of economic growth and favorable conjuncture in the world market allowed Kazakhstan to set and solve certain tasks until 2015 to give the domestic economy an innovative and socially-oriented character [19].

Nevertheless, Kazakhstan is at the tail of the list of countries that are effectively engaged in the development of innovations in medicine. Historically, the USA, Germany, Great Britain and Japan are leaders in this market. Recently, India and China are actively expressing themselves. The share of domestic innovative drugs, even on the domestic market, is very small (a few percent). About $70 \%$ of the resources required for the production of finished medicines are supplied from India, China and other countries, and the volume of exports of finished medicines and pharmaceutical substances from Kazakhstan is less than $0,1 \%$ of global sales. The main reason for this is a sharp reduction in the funding of research in 1990-2007 and a shortage of qualified personnel.

Since there is a large amount of state intervention in Kazakhstan, the responsibility for implementing innovative health projects is directly assigned to medical organizations and the authorized body the Ministry of Health and Social Development of the Republic of Kazakhstan. New methods of prevention, diagnosis and treatment in Kazakhstan are implemented with the support of an authorized state body or randomized on the basis of training, professional development, initiatives of specialists of individual medical organizations.

Since the adoption of the course for industrial and innovative development, Kazakhstan as a result of 2015 reached a maximum in the growth of key indicators of innovative activity. This positive trend is largely due to the successful results of the State Program for Innovative Industrial Development. According to the Committee on Statistics of the Republic of Kazakhstan in 2015, over the last decade we managed to achieve increase in share of innovatively active enterprises in all sectors, exceeding the level of 7\% (Figure 2) from 7,1\% to 7,6\%, while in 2013 this Figure amounted to $5,2 \%$.

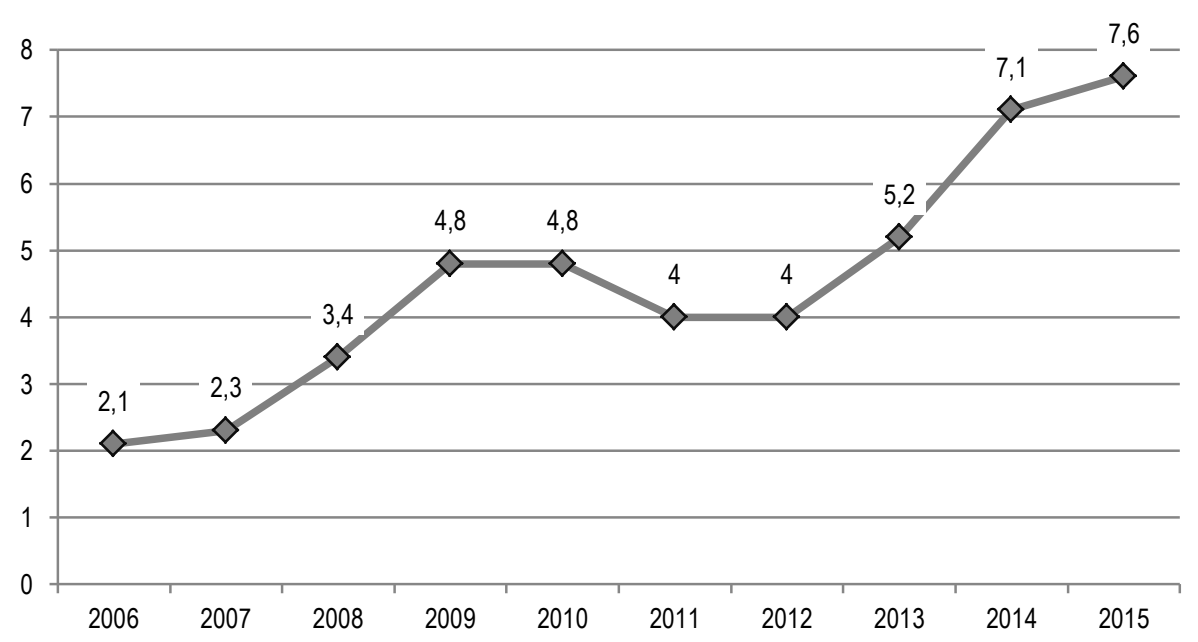

Figure 2 - Share of innovatively active enterprises, \% (own results) 
There is the growth in domestic expenditure on research and development, which reached 208,52 million euro (about 231 million USD) with growth of $18,2 \%$ compared to 2014 , while their share to GDP increased to $0,17 \%$ (Figure 3).

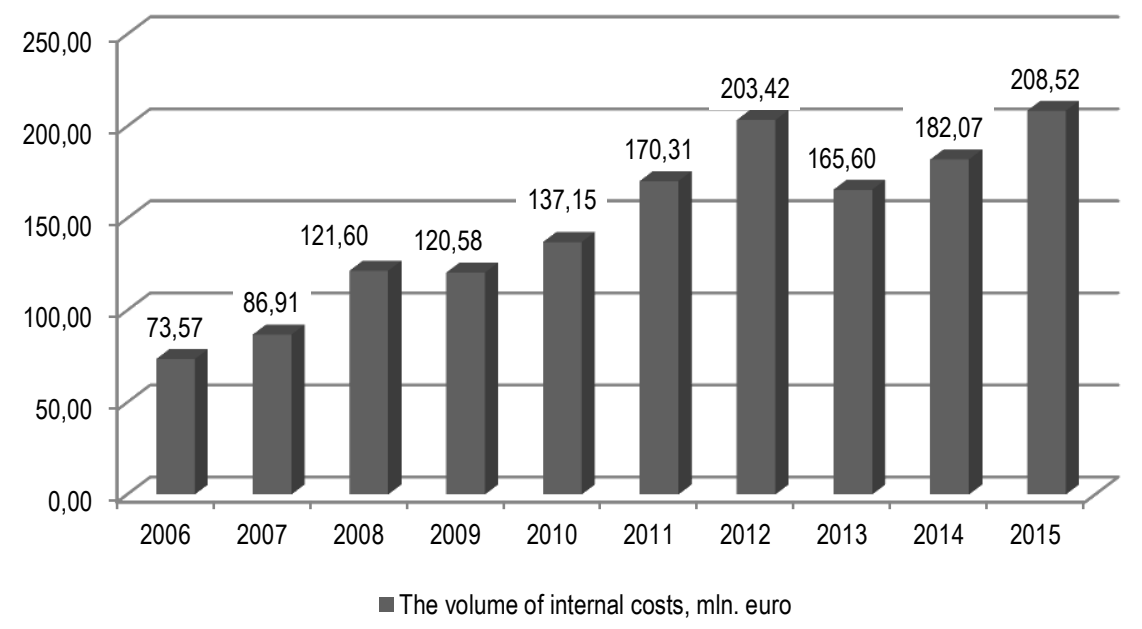

Figure 3 - Domestic expenditures on research and development, mln. euro (own results)

Every year, the current expenditure on technological innovation of healthcare enterprises is growing, in recent years, the volume of innovative products has significantly increased.

According to the recommendations of the World Health Organization the cost of medicine needs to be at least $5 \%$ of GDP for the effective performance of its functions. Alongside with it there remains the influence of factors of inhibition: non-diversified sectorial structure of the economy remains on the low level of economic efficiency of production. Kazakhstan is situated at the end of the list of countries effectively engaged in the development of medical innovations.

The analytical group of the World Economic Forum, all countries participating in the ranking, are divided into three groups depending on the stage of development of the country, determined by the level of GDP per capita and the degree of conditionality of the country by the basic factors. The first category is countries, the economy, which is driven by "production factors". This group includes 38 countries (Kyrgyzstan, Moldova, India, Bangladesh, etc.). The second group is the countries, the economy, which is driven by "management effectiveness" (Armenia, Ukraine, China, etc.). The third group is the countries, the economy, which is driven by innovations (35 countries: Australia, Austria, Finland, Japan, South Korea, USA, Norway, France etc.) [21].

According to the results of the rating in 2014, Kazakhstan, moved through one stage to the next intermediate group (2-3), located between the categories of countries driven by "management effectiveness" and "innovation". This group also includes countries such as Argentina, Brazil, Hungary, Malaysia, Latvia, Poland, the Russian Federation, Turkey and others. In 2015, Kazakhstan retained this provision.

The rating is headed by such countries as Switzerland, Singapore, Finland. Thus, Kazakhstan retains the second result among the CIS countries after Azerbaijan (39th place). Russia occupies the 64th place, Ukraine - 84th, the Kyrgyz Republic - 121st place [24]. 
The global competitiveness index of WEF is formed from a combination of three sub-indexes: "Factors of basic conditions", "Efficiency factors", "Factors of innovation", which are subdivided into factors and sub-factors. According to this system of assessments in Kazakhstan there is an improvement in the factors of "Quality of institutions", "Higher education and professional training", "Factors of innovation", "Competitiveness of companies". However, there was a decline in the rating by the "Health and primary education" factor from 85 to 92.

For the "Innovation potential" factor, the growth of Kazakhstan's position increased by 13 points (in 2013 - 116, in 2014 - 103). There is a growth in the "Quality of scientific research institutions" sub-factor. According to this indicator in 2013 Kazakhstan the 121, in 2014 - 10813 points raised Kazakhstan's rating for "Expenses of companies on research and development" sub-factor (2013 - 107, in 2014 - 94). There were improved linkages between Universities and industry in the field of research and development, in 2014, an increase of 29 points, in 2013 - 119, in 2014 - 90. There was observed a positive shift of Kazakhstan in 2014 on the "Public procurement of high-tech products" sub-factor from 93 to 71 [39].

In the framework of technology commercialization system development of the National Agency for technical development (further - NATD) established 15 commercialization offices and 4 regional commercialization centers, ready to provide support and expert assistance to scientists and innovators in the process of innovations commercialization.

Under the terms of financing investment of NATD in one innovative project should not exceed $49 \%$ of the project cost, with the term of participation in the project to 5 years. In 2014-2015 for the provision of innovative grants there were allocated 8,8 billion tenge from the Republican budget, due to which in 2014 there were funded 37 projects worth 1,7 billion tenge, in 2015 - 129 projects amounting to 7,1 billion tenge, in the reporting period work was carried out for their implementation and monitoring.

According to the NATD innovative activity in organizations of the health system remains on the low level. Quality of submitted applications does not meet the General requirements of NATD, in connection with it projects do not receive a positive decision of the Commission.

Results of an online survey of medical specialists on the innovative activities in the Republic of Kazakhstan have identified the reasons inhibiting the activity of development and implementation of innovations.

In the second half of 2015, we conducted a survey that allowed us to draw certain conclusions about the level of innovative activity in the healthcare of Kazakhstan.The sample of respondents reached 849 human which was attended by specialists of all levels. However, it should be noted that respondents of district medicine made only $15,5 \%$. The number of respondents was dominated by the leaders of various levels (about $47 \%$ ), reflecting their leading role in facilitating innovation in medical institutions.

In general, among the respondents in the occupied positions, the experts occupying leading positions is $46,7 \%$, the heads of the department is $20,6 \%$, the deputies of the first head is $15,3 \%$, the first leaders of the organization is $7,9 \%$, the heads of departments $-3,9 \%$, heads of department $/$ department $-3,5 \%$ and less participated in the survey of heads of sectors $-2,0 \%$ of cases. That is, health professionals in Kazakhstan, actively involved in innovation, are mainly represented by representatives from the capital's regions and cities of the republic, the administrative and management apparatus, in the age category over 40 years.

As shown by the analysis of the questionnaire, the main share of innovations being developed in healthcare organizations falls on practical medicine $-38,6 \%$, education $-9,1 \%$, organizational and managerial technologies $-8,7 \%$ and scientific research $-5,3 \%$. The analysis showed that medicine innovations in Kazakhstan are implemented primarily in the practice of medicine (39\%), although they are born in a research (40\%). According to the authors, insufficient level of innovation attributable to education (less than 10\%) risks of resistance to the innovative development of future professionals and 
to creation of an institutional threat to the backlog of Kazakh medicine. According to the study every tenth medical facility do not introduce innovative technologies, more than half of clinical staff are not involved in the implementation of research programs.

Every fifth healthcare professional is not involved in innovative activities. Unfortunately, the low level of involvement of experts in preclinical studies, where medical innovations are usually originated. The results of the questionnaire showed that only $26,4 \%$ of specialists participated in the development of methodological recommendations for practical health care, $24,6 \%$ of respondents received acts of introducing innovations from different regions of the Republic, 17,7\% had patents of the RK, $17 \%$ participated in the development of clinical Protocols and only $11,4 \%$ had author's certificates of innovation $(r=0.830)$.

Most Kazakhstani doctors and nurses who participated in the survey $(62,4 \%)$ say that we are introducing the borrowed innovations. Introduction to advanced medical technology is a positive process, especially if it encourages professionals to own innovation. According to the estimates of respondents there are already $27 \%$ of the organizations introducing innovations and inventions that are created directly in a medical facility.

The authors note the insufficient level of competence of doctors and nurses for the work with information. Mostly professionals search for information on the Internet (23\%), but not widely discuss it in the professional community at work (17\%). Only $16 \%$ of respondents use scientific publications for new information, while professional culture assumes that $100 \%$ of health workers should regularly read core publications. The authors also note the lack of ability to handle empirical data and, in particular, to use databases of evidence-based medicine and clinical protocols (14\% and $15 \%$, respectively). That is evidence-based medicine that is currently a source of competitive innovation, the ability to use modern research methods it is a mandatory part of professional competence in medicine. Respondents (23\%) noted the lack of expertise and lack of awareness about the achievements of medical science and practice. High efficiency of joint learning within the organization (31\%) confirms the high potential of selflearning forms, which is one of the signs of a professional community.

Another advantage of the network community is a free exchange of information sent and repeatedly checked in the network. The authors believe that overcoming the shortcomings of innovative activity of the Kazakhstan doctors is consisted from stimulation of professional networking communities. Professional medical communities are determined by the type of knower networks, joining self-education factors. More than half $(59 \%)$ of respondents noted difficulties of the staff to have access to resources of scientific and technical information of the organization, while at the network there is freely circulating the professional information at various levels.

Belonging to a professional network community also solves the task to stimulate participants to produce the innovative product. In the medical environment, there are many complaints of excessive workload $(13 \%)$, weak physical infrastructure and inefficiency of the bodies responsible for the development and implementation of the innovation (12\%). Half of the respondents noted the lack of material interest. World experience shows that the professional network of doctors is an effective tool for the creation, accumulation and exchange of information among members of the network. Medical organizations use the medical community as the impact on consumers, as well as a resource for professional growth and career advancement of doctors.

Comparative analysis of factors of influence on staff's involvement in innovative activity shows the presence of significant creative potential in the Kazakh medicine. Training at the workplace allowing partial compensation for the workload of doctors. The high level of demand for internships creates an additional incentive for specialists-innovators. Access to information becoming available in recent years is allowing compensation for the still significant lack of knowledge [30; 31]. 
Based on the analysis of the results of the research of innovative activity in the healthcare of Kazakhstan, we conducted a SWOT-analysis (Table 1):

\section{Table 1- Results of SWOT-analysis of Kazakhstan's healthcare sector}

\begin{tabular}{|c|c|}
\hline Strengths & Weaknesses \\
\hline $\begin{array}{l}\text { - political support of the state at the highest level and } \\
\text { guaranteeing the fulfillment of the social obligations } \\
\text { taken; } \\
\text { - stable epidemiological situation for the majority of } \\
\text { infectious diseases with high immunization coverage; } \\
\text { - good provision of stationary organizations; } \\
\text { - experience of transfer of modern medical } \\
\text { technologies and highly specialized medical care; } \\
\text { - development of transport medicine; } \\
\text { - introduction of the accreditation system; } \\
\text { - creating priorities for the development of domestic } \\
\text { manufacturers of medicines; } \\
\text { - more precise orientation of services for consumers }\end{array}$ & $\begin{array}{l}\text { - low life expectancy, high level of overall mortality in } \\
\text { comparison with the average level of European countries; } \\
\text { - low level of the share of GDP for financing healthcare; } \\
\text { - high level of private healthcare expenditure; } \\
\text { - insufficient level of financing of primary healthcare; } \\
\text { - the lack of mechanisms for joint responsibility for health; } \\
\text { - insufficient participation of the private sector in providing } \\
\text { a guaranteed volume of free medical care; } \\
\text { - low level of corporate governance; } \\
\text { - low labor motivation and professionalism of medical } \\
\text { personnel; } \\
\text { - insufficient medicines at the outpatient level; } \\
\text { - insufficient shared responsibility of the population for their } \\
\text { health; } \\
\text { - the complexity of forecasting for a long period due to } \\
\text { changes in the market conditions and volatility of the } \\
\text { national currency exchange rate }\end{array}$ \\
\hline Opportunities & Threats \\
\hline $\begin{array}{l}\text { - introduction of social health insurance based on } \\
\text { implemented market mechanisms (a single payer } \\
\text { was established, modern methods of payment were } \\
\text { introduced, taking into account the developed } \\
\text { protocols and standards); } \\
\text { - investment support of the World Bank and other } \\
\text { international financial institutions; } \\
\text { - development of the medical tourism market; } \\
\text { - increasing competitiveness in the health care } \\
\text { market and possible direct investment in health care; } \\
\text { - transfer of knowledge and best practices through } \\
\text { intensive communication and cooperation with } \\
\text { European experts }\end{array}$ & $\begin{array}{l}\text { - further worsening of the global economic situation; } \\
\text { - increased demand for medical services; } \\
\text { - the growing costs of health care not covered by budgetary } \\
\text { funds alone; } \\
\text { - growth of non-communicable diseases; } \\
\text { - the presence of natural foci of especially dangerous } \\
\text { infections on the territory of the country and the weakening } \\
\text { of the role of the sanitary and epidemiological service; } \\
\text { - counterfeit medicinal products }\end{array}$ \\
\hline
\end{tabular}

In the opinion shared by the medical community, the main reason for the low innovation activity is the level of knowledge of professionals on the latest achievements of science, lack of trained personnel and lack of target financing of innovation in healthcare.

Conclusion and directions for further research. Kazakhstan medicine largely lags behind both of the world's level of development and demands of modern society. The main reason for this is the drastic reduction of research funding in 1990-2007 and the shortage of qualified personnel.

Low innovation activity of health care organizations not only reduces the quality of life of the population, but also poses a severe risk to increase in the future. Scientific organizations of the healthcare system must recognize the critical role of innovation in successful organization of its activities, conquest of new markets, strengthening competitive advantages. 
Results of the analysis also indicate the need to intensify inter-sectorial cooperation and involvement of business structures in the sphere of development and introduction of new medical technologies in practical public health. Expert analysis conducted during the study has identified promising opportunities and directions of development of innovative activities in healthcare. As breakthrough technologies there were marked innovative forms of organization of medical-diagnostic process, new approaches to staffing, efficient management of organizational projects. As priority directions of development there was defined the development of innovative infrastructure and innovative forms of the organization of the activities of the institution. Opportunity to upgrade innovation activities in healthcare is the integration of science and business, with the goal of commercialization of medical products by creating a public-private partnership or the transition of health care institutions in the new economic mechanism, with the involvement of extra-budgetary allocations.

To overcome barriers in the process of innovation in health care, it is necessary:

- to create a cohesive multidisciplinary team, the following principles of independence, evidence and transparency;

- ensure effective public-private partnerships in the implementation of innovative projects;

- to stimulate the attraction of foreign investment in high technology high-tech healthcare;

- identify priority areas of scientific and technical activities for the implementation of competitive applications;

- create channels of external and internal information;

- strengthen interaction with other research institutions and research-and-production enterprises.

1. Abrhám, J., Bilan, Y., Krauchenia, A., \& Strielkowski, W. (2015). Planning horizon in labour supply of Belarusian small entrepreneurs. Economic Research-Ekonomska Istraživanja, 28(1), 773-787.

2. Ahmed, A., McGough, D., \& Mateo-Garcia, M. (2017). Testing innovative technologies for retrofitting: Coventry University as a living lab. Entrepreneurship and Sustainability Issues, 4(3), 257-270, DOl: http://dx.doi.org/10.9770/jesi.2017.4.3S(2).

3. Allabouche, K., Diouri, O., Gaga, A., \& El Amrani El Idrissi, N. (2016). Mobile phones' social impacts on sustainable human development: case studies, Morocco and Italy. Entrepreneurship and Sustainability Issues, 4(1), 64-73, DOI: http://dx.doi.org/10.9770/jesi.2016.4.1(6).

4. Aubakirova, A., Bekembaeva, G., \& Mergentay, A. (2014). Assessment of the level of innovative activity of health organizations of different levels, analysis of the factors and reasons for limiting the introduction of new medical technologies into the health system of the Republic of Kazakhstan. group-global.org. Retrieved from http://groupglobal.org/sites/default/files/publications/Оценка\%20инновационного\%20потенциала.docx.

5. Baiterek National Managing Holding JSC // "National Agency for Technological Development" // Ministry of Industry and New Technologies of the Republic of Kazakhstan. (2013). Report on trends of innovation development in the Republic of Kazakhstan and in the World.

6. Bekembayeva. G., Koykov. V., Mergentay. A., Mussina G., \& Solodovnikov M. (2015). Current state of investment activity in the field of health care in Kazakhstan. Success of modern natural study, 9(1), 20-33. Retrieved from http://www.naturalsciences. ru/ru/article/view?id=35520.

7. Boonyachut, S. (2016). Sustainability of community's entrepreneurship: case of floating market at Ladmayom. Entrepreneurship and Sustainability, 4(2), 211-219, DOI: http://dx.doi.org/10.9770/jesi.2016.4.2(8).

8. Čábelková, I., Strielkowski, W., \& Mirvald, M. (2015). Business influence on the mass media: a case study of 21 countries. Transformation in Business \& Economics, 14(1), 65-75.

9. Chiabai, A., Platt, S., \& Strielkowski, W. (2014). Eliciting users' preferences for cultural heritage and tourism-related eservices: a tale of three European cities. Tourism Economics, 20(2), 263-277.

10. Dalati, S., \& Al Hamwi, S.E. (2016). Sustainable development in higher education through service quality and price fairness: empirical evidence from private universities in Syria. Entrepreneurship and Sustainability Issues, 4(1), 25-38, DOI: http://dx.doi.org/10.9770/jesi.2016.4.1(3).

11. Fennell, M. (2008). The New Medical Technologies and the Organization of Medical Science and Treatment. Journal Health Serv Res. 43 (1 Pt 1), DOl: http://www.ncbi.nlm.nih.gov/pmc/articles/PMC2323138/.

12. García-Fuentes, M.A., \& de Torre, C. (2017). Towards smarter and more sustainable regenerative cities: the REMOURBAN model. Entrepreneurship and Sustainability Issues, 4(3), 328-338, DOI: http://dx.doi.org/10.9770/jesi.2017.4.3S(8). 
13. Glazar, O., \& Strielkowski, W. (2010). Turkey and the European Union: possible incidence of the EU accession on migration flows. Prague Economic Papers, 19(3), 218-235.

14. Ignatavičius, R., Tvaronavičienè, M., \& Piccinetti, L. (2015). Sustainable development through technology transfer networks: case of Lithuania. Entrepreneurship and Sustainability Issues, 4(3), 261-267, DOI: DOI: http://dx.doi.org/10.9770/jssi.2015.4.3(6).

15. Kazakhstan investment attractiveness survey. (2014). invest.gov.kz. Retrieved from http://invest.gov.kz/uploads/files/2015/08/19/privlekatelnost-kazahstana.pdf.

16. Kevin. J., Scanlon. M., \& Lieberman. A. (2014). Commercialization of Medical Technologies. www.ncbi.nlm.nih.gov. Retrieved from http://www.ncbi.nlm.nih.gov/pmc/articles/PMC2267620/.

17. Kiškis, M., Limba, T., \& Gulevičiütè, G. (2016). Business value of Intellectual Property in Biotech SMEs: case studies of Lithuanian and Arizona's (US) firms. Entrepreneurship and Sustainability Issues, 4(2), 221-234, DOI: http://dx.doi.org/10.9770/jesi.2016.4.2(11)

18. Laužikas, M., Miliūtè, A, Tranavičius, L., \& Kičiatovas, E. (2016). Service Innovation Commercialization Factors in the Fast Food Industry. Entrepreneurship and Sustainability Issues, 4(2), 108-128, DOI: http://dx.doi.org/10.9770/jesi.2016.4.2(1).

19. Ministry of industry and new technologies of the Republic of Kazakhstan. (2013). Strategic plan of the Ministry of industry and new technologies of the Republic of Kazakhstan for 2014-2018. Retrieved from http://adilet.zan.kz/rus/docs/P1300001574

20. Mouraud, A. (2017). Innovative time series forecasting: auto regressive moving average vs deep networks. Entrepreneurship and Sustainability Issues, 4(3), 282-293, DOI: http://dx.doi.org/10.9770/jesi.2017.4.3S(4.

21. National Bank of the Republic of Kazakhstan. (2015). Report of the on 2015. www.nationalbank.kz. Retrieved from http://www.nationalbank.kz/cont//O_2015_\%20pycck_.pdf.

22. Oates, M., Melia, A., \& Ferrando, V. (2017). Energy balancing accross cities: Virtual Power Plant prototype and iURBAN case studies. Entrepreneurship and Sustainability Issues, 4(3), 351-363, DOl: http://dx.doi.org/10.9770/jesi.2017.4.3S(10).

23. Oganisjana, K., Surikova, S., \& Laizāns, T. (2015). Factors influencing social innovation processes in Latvia: qualitative research perspective. Entrepreneurship and Sustainability Issues, 3(2), 186-197, DOI: http://dx.doi.org/10.9770/jesi.2015.3.2(6).

24. Olefirenko, O., Petrenko, E., Shevyakova, A., \& Zhartay, Z. (2016). Towards economic security through diversification: case of Kazakhstan. Entrepreneurship and Sustainability Issues, 5(4), 509-518, DOI: http://dx.doi.org/10.9770/jssi.2016.5.4(6).

25. Passerini, F., Sterling, R., Keane, M., Klobut, K., \& Costa, A. (2017). Energy efficiency facets: innovative district cooling systems. Entrepreneurship and Sustainability Issues, 4(3), 310-318, DOI: http://dx.doi.org/10.9770/jesi.2017.4.3S(6).

26. Pauceanu, A.M. (2016). Innovation and entrepreneurship in Sultanate of Oman - an empirical study. Entrepreneurship and Sustainability Issues, 4(1), 83-99, DOI: http://dx.doi.org/10.9770/jesi.2016.4.1(8).

27. Perfido, D., Raciti, M., Zanotti, C., Chambers, N., Hannon, L., Keane, M., Clifford, E., \& Costa, A. (2017). Towards sustainable water networks: automated fault detection and diagnosis. Entrepreneurship and Sustainability Issues, 4(3), 339-350 DOI: http://dx.doi.org/10.9770/jesi.2017.4.3S(9).

28. Raudeliūnienè, J., Stadnik, B., \& Kindarytè, R. (2016). Knowledge appliance process: theoretical and practical evaluation aspects. Entrepreneurship and Sustainability Issues, 3(4), 368-379, DOI: http://dx.doi.org/10.9770/jesi.2016.3.4(5).

29. Rezk, M.A., Ibrahim, H.H., Radwan, A., Sakr, M.M., Tvaronavičienè, M., \& Piccinetti, L. (2016). Innovation magnitude of manufacturing industry in Egypt with particular focus on SMEs. Entrepreneurship and Sustainability Issues, 3(4), 307-318, DOI: http://dx.doi.org/10.9770/jesi.2016.3.4(1)

30. Shevyakova, A. (2014). Features of the socio-economic stratification in the Republic of Kazakhstan. Social sciences for regional development in 2014: Proceedings of the IX International Scientific Conference (17-18 October 2014). Daugavpils University Latvia.

31. Shevyakova, A., \& Sharip, B. (2014). Introduction of innovative technologies as a factor of change in the organizational culture of new medical profession. Entrepreneurship, social organization in network structures. Experience and development prospects in Central and Eastern European Conference (23-25 May 2016). Lublin Catholic University of John Paul II.

32. Štitilis, D., Pakutinskas, P., \& Malinauskaité, I. (2016). Preconditions of sustainable ecosystem: cyber security policy and strategies. Entrepreneurship and Sustainability Issues, 4(2), 174-182, DOI: http://dx.doi.org/10.9770/jesi.2016.4.2(5).

33. Strielkowski, W. (2016). Entrepreneurship, sustainability, and solar distributed generation. Entrepreneurship and Sustainability Issues, 4(1), 9-16, DOI: http://dx.doi.org/10.9770/jesi.2016.4.1(1).

34. Strielkowski, W., \& Čábelková, I. (2015). Religion, Culture, and Tax Evasion: Evidence from the Czech Republic. Religions, 6(2), 657-669

35. Strielkowski, W., \& Weyskrabova, B. (2014). Ukrainian labour migration and remittances in the Czech Republic. Tijdschrift voor economische en sociale geografie, 105(1), 30-45.

36. Tvaronavičienè, M. (2016). Entrepreneurship and energy consumption patterns: case of households in selected countries. Entrepreneurship and Sustainability Issues, 4(1), 74-82, DOI: http://dx.doi.org/10.9770/jesi.2016.4.1(7).

37. Tvaronavičienè, M., \& Černevičiütè, J. (2015). Technology transfer phenomenon and its impact on sustainable development. Journal of Security and Sustainability Issues, 5(1), 87-97, DOI: http://dx.doi.org/10.9770/jssi.2015.5.1(7).

38. Tvaronavičiené, M., Razminienè, K., \& Piccinetti, L. (2015). Cluster efficiency study through benchmarking. Entrepreneurship and Sustainability Issues, 3(2), 120-128, DOl:http://dx.doi.org/10.9770/jesi.2015.3.2(0).

39. World Bank. (2015). Kazakhstan: Adjusting to Low Oil Prices, Challenging Times Ahead. www.worldbank.org. Retrieved 
from http://www.worldbank.org/en/country/kazakhstan/publication/economic-update-fall-2015.

40. Zemlickiene, V., Mačiulis, A., \& Tvaronavičienè, M. (2017). Factors impacting the commercial potential of technologies: expert approach. Technological and Economic Development of Economy, 23(2), 410-427, DOl: http://dx.doi.org/10.3846/20294913.2016.1271061.

A. Шевякова, $\mathrm{PhD}$, науковий співробітник кафедри маркетингу, Південно-Уральський державний університет (м. Челябінськ, Росія);

Б. Шаріn, DBA, науковий співробітник, Алматинський університет управління (м. Алмати, Казахстан)

Оцінювання інноваційної діяльності медичних закладів Казахстану

У статті розелянуто основні тенденції розвитку охорони здоров'я в Республіці, здійснено аналіз інноваційноі діяльності в медицині Казахстану. Розкрито сутність та необхідність впровадження інноваційних технологій, що в сучасних умовах є одним із пріоритетних напрямів зміни організаційної культури. Визначено, що умови сьогодення призводять до появи нових медичних професій, що дозволяє диверсифікувати медичний персонал та спрямувати його на вирішення актуальних проблем медичних установ.

Ключові слова: інновації, медицина, охорона здоров'я, медичні технології, інноваційна діяльність.

A. Шевякова, PhD, научный сотрудник кафедры маркетинга, Южно-Уральский государственный университет (г. Челябинск, Россия);

Б. Шарun, DBA, научный сотрудник, Алматинский университет управления (г. Алматы, Казахстан)

Оценка инновационной деятельности медицинских учреждений Казахстана

В статье рассмотрены основные тенденции развития здравоохранения в Республике, осуществлен анализ инновационной деятельности в медицине Казахстана. Раскрыта сущность и необходимость внедрения инновационных технологий, что в современных условиях является одним из приоритетных направлений изменения организационной культуры. Определено, что условия настоящего приводят к появлению новых медицинских профессий, что позволяет диверсифицировать медицинский персонал и направить его на решение актуальных проблем медицинских учреждений.

Ключевые слова: инновации, медицина, здравоохранение, медицинские технологии, инновационная деятельность.

Отримано 08.01.2017 p. 